\title{
Nitrogen Fertilization Guidelines for Potato Production in Florida ${ }^{1}$
}

\author{
Lincoln Zotarelli, Tara Wade, Gary K. England, and Christian T. Christensen²
}

\section{Introduction}

This publication focuses on the nitrogen $(\mathrm{N})$ fertilizer best management practices (BMP) for potato crop in Florida. The aim is to provide management strategies that comply with statewide BMP guidelines to maximize yield and economic return while minimizing $\mathrm{N}$ losses to the environment. The guidelines presented result from field-based research conducted by UF/IFAS and lay out the foundation for future precision agriculture efforts for potato production in Florida. Most of the research trials were conducted in large plots in commercial conditions. This document is divided into three main sections. The first section describes the potato nutrient demand for different plant development stages. The second section summarizes the research findings for $\mathrm{N}$ fertilizer rate application and timing. The third section provides a practical guide for $\mathrm{N}$-fertilizer management for potatoes in Florida.

In summary, this document lays out a new set of recommendations for $\mathrm{N}$-fertilizer management based on tuber yield goal and $4 \mathrm{R}$ principles. The information and data presented in this document support the adjustment of the current UF/IFAS recommended rate of $200 \mathrm{lb} /$ acre $\mathrm{N}$ for potato production to a range of 200-250 lb/acre based on tuber yield goal and economic return. These revisions will allow potato producers to maintain economically viable yields and sustainable operations while mitigating water-quality impacts associated with overfertilization, improper timing of fertilizer application, and high rainfall events. This publication's target audience is potato growers, Extension agents, crop consultants, representatives of the fertilizer industry, state and local agencies, students, instructors, researchers, and interested Florida citizens.

\section{Potato Nitrogen Requirements}

Understanding the dynamics of potato plant growth and $\mathrm{N}$ uptake in response to $\mathrm{N}$-fertilization is the initial step to establish a proper guideline for $\mathrm{N}$-fertilization for sustainable production. Nitrogen uptake (also known as plant $\mathrm{N}$ accumulation) by potato crop is determined by the product of dry-matter accumulation of the plant tissues (shoots, roots, and tubers) and correspondent $\mathrm{N}$ concentration in each plant tissue. Typically, $\mathrm{N}$ uptake is very slow at the early growth stages, rapidly increasing with plant growth. After tuber initiation, there is a predominant migration of nutrients from the shoots to tubers, followed by a decrease in $\mathrm{N}$ uptake toward the tuber maturation stage. The typical $\mathrm{N}$ uptake timing and distribution between shoots and tubers are explained in detail below and visually presented in Figure 1.

Growth Stage I-Sprout Development: After planting, the sprout development stage lasts about 20 to 25 days, depending on the depth of seed planting as well as air and

1. This document is HS1429, one of a series of the Horticultural Sciences Department, UF/IFAS Extension. Original publication date December 2021. Visit the EDIS website at https://edis.ifas.ufl.edu for the currently supported version of this publication.

2. Lincoln Zotarelli, associate professor, Horticultural Sciences Department; Tara Wade, assistant professor, Food and Resource Economics Department, UF/IFAS Southwest Florida Research and Education Center, Immokalee, FL; Gary K. England, retired Extension center director and regional specialized agent IV, UF/IFAS Hastings Agricultural Extension Center, Hastings, FL; and Christian T. Christensen, Extension center director and regional specialized agent II, UF/IFAS Hastings Agricultural Extension Center, Hastings, FL; UF/IFAS Extension, Gainesville, FL 32611.

The Institute of Food and Agricultural Sciences (IFAS) is an Equal Opportunity Institution authorized to provide research, educational information and other services

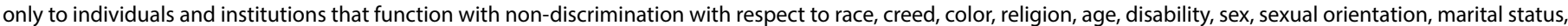

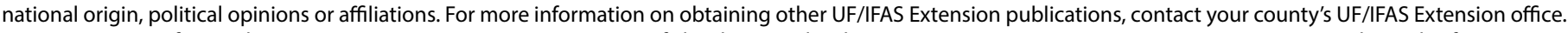
U.S. Department of Agriculture, UF/IFAS Extension Service, University of Florida, IFAS, Florida A \& M University Cooperative Extension Program, and Boards of County Commissioners Cooperating. Nick T. Place, dean for UF/IFAS Extension. 
soil temperatures. Roots begin to develop at the base of the emerging sprouts (Miller and Hopkins 2008). Despite the low $\mathrm{N}$ uptake during this stage and the fact that the seed piece provides some of the nutritional resources for the initial plant development, low soil-available $\mathrm{N}$ can compromise tuber yield and should be avoided (Rens et al. 2018) by applying $\mathrm{N}$-fertilizer during soil preparation near planting time or during planting. The sprout development stage ends with the plant emergence.

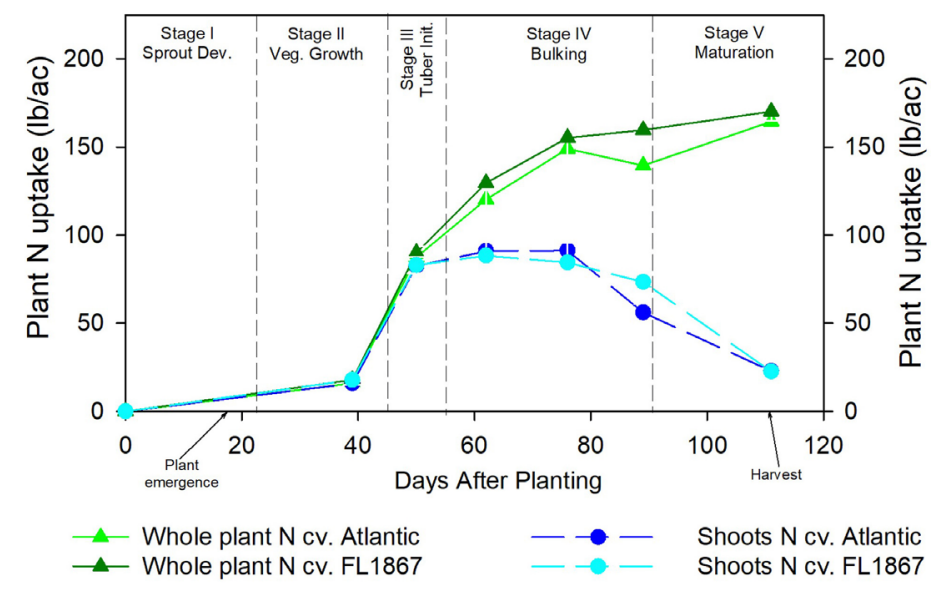

Figure 1. Potato $\mathrm{N}$ uptake (lb/acre) in whole plant (shoots and tubers) and aboveground (shoots) of cultivars Atlantic and FL1867 cultivated in Florida. Data source: Rens et al. (2016).

Credits: Lincoln Zotarelli, UF/IFAS

Growth Stage II-Vegetative Growth: Vegetative growth is characterized by the fast growth of the shoots and the rapid uptake of $\mathrm{N}$ between plant emergence and tuber initiation. In this stage, plant shoots are the dominant sink for $\mathrm{N}$, and the total $\mathrm{N}$ uptake can reach up to $100 \mathrm{lb} /$ acre of $\mathrm{N}$ (Figure 1). An adequate supply of $\mathrm{N}$ in the early stages will ensure the canopy development needed to sustain photosynthesis, which will later supply carbohydrates and nutrients for tuber growth and bulking. In Florida, this period lasts between plant emergence and 45-55 days after planting (DAP).

Growth Stage III-Tuber Initiation: The tuber initiation stage is the most remarkable stage, where tubers start forming at stolon tips. This stage can last 10-14 days (Figure 1 ), and any water or temperature stress can compromise the final yield. For some cultivars, this stage coincides with the flowering (Gudmestad 2008) and marks the peak of $\mathrm{N}$ uptake in the shoots. At this stage, tubers become the primary sink for nutrients, including N. Maximization of the utilization of $\mathrm{N}$ available by the potato plants can be achieved with $\mathrm{N}$-fertilizer application between planting and tuber initiation.
Growth Stage IV-Tuber Bulking: This stage is characterized by fast tuber growth between 55 and 85 days after planting. The photosynthesis occurring in the leaves is responsible for the continued supply of carbohydrates and nutrients to tubers. In early-maturing cultivars, shoot senescence is the indication of nutrient remobilization from shoots to tubers. In Florida, after 80 DAP, toward the end of the bulking period, the plant's overall $\mathrm{N}$ uptake is drastically reduced (Figure 1). Late application of $\mathrm{N}$ (after tuber initiation, or 55 DAP) can stimulate excessive vegetative growth of shoots, consequently reducing tuber yield.

Growth Stage V-Tuber Maturation: The maturation stage is when most of the aboveground tissues are senesced and tuber growth is slower. Tuber skin sets and tuber drymatter content reaches a maximum weight. At the harvest, typically, tubers concentrate about $85 \%$ of the total plant $\mathrm{N}$ uptake, which are exported out of the fields.

\section{Potential Tuber Yield and $\mathrm{N}$-Fertilizer Application Timing for Florida}

Most of the potatoes cultivated in Florida are early- to medium-maturing cultivars. These cultivars require less than 55 days to accumulate more than $90 \%$ of the aboveground biomass (Rens et al., "Rate and Timing," 2015) needed to sustain tuber growth during the bulking period. This physiological characteristic reiterates the need for $\mathrm{N}$ fertilizer application between planting and tuber initiation stages. Conversely, late-maturing cultivars (e.g., Russet Burbank), which are commonly cultivated in the northern states, generally respond to the application of nutrients during the tuber bulking stage, which results in new vegetative growth to maintain photosynthesizing leaf area as older leaves senesce (Stark and Westerman 2008). Late-maturing cultivars grown in western production regions have the potential and environmental conditions for higher tuber yields. For example, a comparison of average potato yield between Florida and Oregon illustrates the influence of the environment and growing conditions on tuber yield. In 2019, the mean potato yield for Florida was $275 \mathrm{cwt} / \mathrm{ac}$, while in the same year, Washington state produced $640 \mathrm{cwt} /$ acre (USDA 2020).

Because early- to medium-maturity cultivars are predominant in Florida, adequate timing and rate of fertilizer application at earlier plant stages are required to ensure nutrient availability in the crop root zone. 


\section{Summary of Research Findings from Field Studies on N-Fertilizer Rate and Timing of Application for Potatoes in Florida}

Florida sandy soils are very susceptible to nitrate leaching, making the synchronization of soil-available $\mathrm{N}$ and plant $\mathrm{N}$ uptake very challenging, considering the short potato crop season and irregular rainfall patterns (Stanley and Toor 2010). Research trials conducted between 1949 and 1998 led to an update on N-fertilizer recommendations for potatoes in Florida from $175 \mathrm{lb} / \mathrm{acre}$ of $\mathrm{N}$ to $200 \mathrm{lb} /$ acre of $\mathrm{N}$ in 2000 (Hochmuth and Hanlon 2011). The trials used to determine the $\mathrm{N}$-fertilizer recommendation had an average optimum tuber marketable yield of $223 \pm 67 \mathrm{cwt} /$ acre ( \pm standard deviation of the mean). More information on $\mathrm{N}$-fertilizer studies conducted before 1998 can be found in EDIS article SL346, "A Summary of N, P, and K Research with Potato in Florida" (https://edis.ifas.ufl.edu/publication/ CV233).

Several field studies conducted by UF/IFAS between 2010 and 2016 focused on optimizing $\mathrm{N}$-fertilizer rate and timing of application for maximization of plant $\mathrm{N}$ uptake and tuber yield. Most trials were conducted on commercial production areas, with $\mathrm{N}$-fertilizer rates ranging from 100 to $300 \mathrm{lb} /$ acre of $\mathrm{N}$ with varying applications at preplant, planting, emergence, and tuber initiation timings in rotation with sorghum-sudangrass. Overall, these trials reported an expressive increase in marketable tuber yield compared to previous studies summarized by Hochmuth and Hanlon (2011). The average total tuber yield was 331 $\pm 68 \mathrm{cwt} /$ acre and the average marketable tuber yield of $274 \pm 79 \mathrm{cwt} / \mathrm{ac}$. Part of the increase in tuber yield over the years can be attributed to overall improvements in crop management (e.g., disease and weed control, seed quality, irrigation management), and most importantly, to the adoption of controlled-rate application systems with banding application of fertilizers near the crop root zone instead of broadcasting.

Regarding timing, the application of soluble $\mathrm{N}$-fertilizer many days before planting (e.g., around fumigation time, 30-40 days before planting) was shown to have great susceptibility to $\mathrm{N}$ leaching, and therefore this practice is discouraged. In commercial potato fields receiving $50 \mathrm{lb} /$ acre preplant $\mathrm{N}$-fertilizer at fumigation resulted in most of the soil $\mathrm{N}$ being lost from the $0-6$ inch soil depth layer before the plant emergence after a cumulative rainfall of 2.5 inches (Rens et al., "Commercial Evaluation," 2016;
Zotarelli et al. 2015; Zotarelli et al. 2014). The N-fertilizer use efficiency (NFUE) of the preplant $\mathrm{N}$ application measured with ${ }^{15} \mathrm{~N}$ isotope was only $11 \%$ (Rens et al., "Fertilizer Nitrogen Uptake Efficiencies," 2016); this means that if $100 \mathrm{lb} /$ acre of $\mathrm{N}$ was applied at preplant, only $11 \mathrm{lb} /$ acre of $\mathrm{N}$ was effectively used by the potato plant, and the remaining $89 \mathrm{lb} /$ acre of $\mathrm{N}$ was not recovered in the root zone, likely being lost to the environment. Conversely, $\mathrm{N}$-fertilizer application just prior to planting (or at planting using a planter equipped with fertilizer hoppers) will invariably increase the FNUE to 18\% (da Silva et al. 2018). Although the N-fertilizer application timings of preplant and at planting result in a lower NFUE compared to later application timings, lower potato yields were observed when no $\mathrm{N}$-fertilizer was applied at preplant or emergence (Rens et al. 2018), indicating that availability of $\mathrm{N}$ during the sprout development stage is required for fostering early plant development and yield. Thus, applying 50-75 lb/acre of $\mathrm{N}$-fertilizer at planting, or a few days before planting, will support the initial plant growth until the next $\mathrm{N}$-fertilizer application at plant emergence.

The most significant demand for $\mathrm{N}$ by the potato plants occurs between 40 and 80 days after planting (Figure 1); thus, ensuring adequate soil $\mathrm{N}$ availability during this period is crucial to avoid a reduction in tuber yield. Therefore, $\mathrm{N}$-fertilizer application between plant emergence and tuber initiation (e.g., 25-55 DAP) is the ideal application window to maximize soil $\mathrm{N}$ availability and plant $\mathrm{N}$ uptake synchronization, resulting in an NFUE in the order of $57 \%-62 \%$ (Rens et al., "Fertilizer Nitrogen Uptake Efficiencies," 2016).

The $\mathrm{N}$-fertilizer rates for emergence and tuber initiation application timings were also investigated. Total and marketable tuber yield for chipping potato cultivars typically peaked when $\mathrm{N}$ rate at plant emergence was between 100 and $125 \mathrm{lb} /$ acre of $\mathrm{N}$ for production seasons with more regular rainfall distribution (Rens et al., "Rate and Timing," 2015; Rens et al., "Biomass Accumulation," 2015; Rens et al. 2018; Zotarelli et al. 2015; Zotarelli et al. 2014). N-fertilizer rates up to $150 \mathrm{lb} /$ acre can be considered in seasons with excessive rainfall after the first $\mathrm{N}$ application at planting. For example, Rens et al. (2018) described that marketable yield was maximized with emergence N-rates $114-150 \mathrm{lb} /$ acre when initial soil $\mathrm{N}$ was limited due to a cumulative rainfall of 5 inches after $50 \mathrm{lb} /$ acre of $\mathrm{N}$ was applied at preplant.

Application of $\mathrm{N}$-fertilizer at the tuber initiation stage is reported to have an NFUE of around 62\%, which indicates an appropriate timing for $\mathrm{N}$-fertilizer application. However, there has been limited yield response to 
very high $\mathrm{N}$-fertilizer application rates at that stage of development. Several field trials across multiple years compared the tuber yield response of $50 \mathrm{vs.} 100 \mathrm{lb} / \mathrm{acre}$ of $\mathrm{N}$ applied at tuber initiation, approximately 45-55 DAT (Zotarelli et al. 2014, 2015; Rens et al., "Rate and Timing," 2015; Rens et al., "Biomass Accumulation," 2015). None of the trials indicated that marketable potato yield, plant biomass accumulation, or tuber quality were significantly improved with $100 \mathrm{lb} /$ acre over $50 \mathrm{lb} /$ acre of $\mathrm{N}$, even in seasons with cumulative rainfall of 5.2-5.6 inches between tuber initiation and harvest (Rens et al., "Rate and Timing," 2015; Rens et al., "Biomass Accumulation,” 2015; Zotarelli et al. 2015; Zotarelli et al. 2014). Moreover, supplying a large proportion of the $\mathrm{N}$ at tuber initiation increased the amount of residual soil $\mathrm{N}$ in the field after harvest (Rens et al., "Commercial Evaluation," 2016), making it more susceptible to leaching. As reported in these field studies, in crop seasons with high precipitation, the application of $\mathrm{N}$ rates below $200 \mathrm{lb} /$ acre may not supply sufficient $\mathrm{N}$ for the potato crop due to the excessive $\mathrm{N}$ losses. Conversely, total $\mathrm{N}$ application rates above $250 \mathrm{lb} / \mathrm{acre}$ showed no significant increase in plant biomass, plant $\mathrm{N}$ uptake, or tuber yield. Overall, a lower NFUE was reported with the increase of $\mathrm{N}$ fertilizer rates (Zotarelli et al. 2015; Zotarelli et al. 2014). Thus, three $\mathrm{N}$-fertilizer application timings, at planting, plant emergence, and tuber initiation, are ideal for potato productions in Florida. However, $\mathrm{N}$ fertilizer distribution among these three application timings can be balanced considering the crop uptake demand, potential tuber yield, and environmental conditions, such as in-season rainfall.

The combined results (576 field observations) from multiple year-location studies were used to determine the tuber yield response variabilities and plant $\mathrm{N}$ uptake from several $\mathrm{N}$-fertilizer rate treatments. The median of total tuber yield was $346 \mathrm{cwt} / \mathrm{ac}$, with $90 \%$ of the observations between 230 and $405 \mathrm{cwt} / \mathrm{ac}$. (The median is the middle score for a set of data that has been arranged in order of magnitude. The median is less affected by outliers and skewed data.) The median tuber marketable tuber yield was $297 \mathrm{cwt} / \mathrm{acre}$ (marketable tuber yield is considered tuber size greater than $17 \%$ inches with no visible defects), with $90 \%$ of the observations between 150 and $360 \mathrm{cwt} /$ acre (Figure 2).

The correspondent total plant $\mathrm{N}$ uptake from tissues and tubers was also determined for each tuber yield measurement. The median of plant $\mathrm{N}$ uptake was $125 \mathrm{lb} /$ acre of $\mathrm{N}$, with $90 \%$ of the observations between 76 and $170 \mathrm{lb} / \mathrm{acre}$ of $\mathrm{N}$ (Figure 2). A significant linear correlation between tuber yield and plant $\mathrm{N}$ uptake was determined (Figure 3). This relationship indicates that for each $1000 \mathrm{lb} / \mathrm{acre}$ of fresh tubers $(100 \mathrm{cwt} / \mathrm{ac})$, potato plants need to uptake on average $30 \mathrm{lb} /$ acre of $\mathrm{N}$ (e.g., the slope of the linear regression). Therefore, to sustain tuber production levels between 300 and $400 \mathrm{cwt} / \mathrm{ac}$, potato plants will require 115 to $144 \mathrm{lb} /$ acre of $\mathrm{N}$ available in the soil for uptake (not fertilizer rate) between growth stages II, III, and IV. With the combination of plant $\mathrm{N}$ requirement and the NFUE in these cropping systems, it is then possible to determine the $\mathrm{N}$-fertilizer rate according to the yield goal.
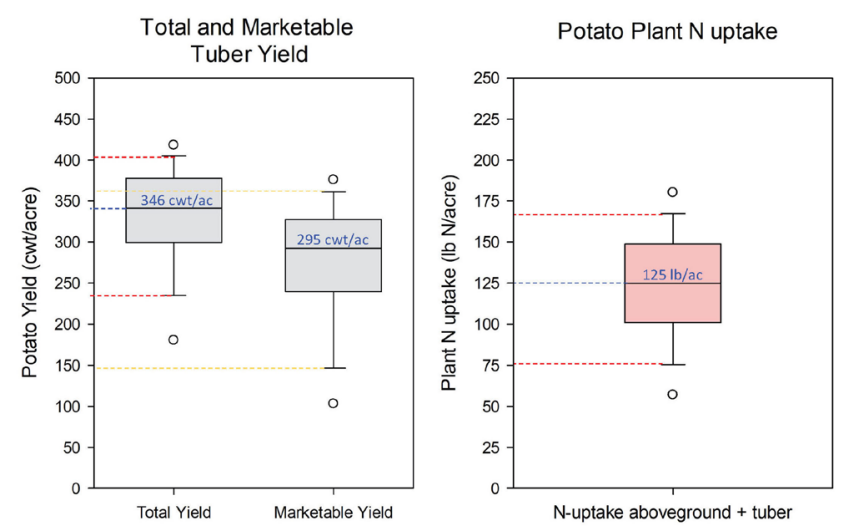

Figure 2. Box plot representation of total and marketable tuber yield (tuber size $>17 / 8$ inches) and respective potato plant $\mathrm{N}$ uptake (shoots and tubers) of cultivars Atlantic and FL1867 (total number of observations $=576$ ) cultivated in six commercial fields of northeast Florida between 2010 and 2014. Box plot interpretation, upper and lower circles represent the outlier measured values. Lower and upper whiskers represent the 5 th and 95 th percentile of the measured values, respectively; thus, the interval between whiskers represents $90 \%$ of the observations. The box's lower and upper limits represent the 25th and 75th percentile of the measured values, and the box centerline represents the median value (separating the higher half from the lower half).

Credits: Data source: (Rens et al., "Rate and Timing," 2015; Rens et al., "Commercial Evaluation," 2016; Rens et al., "Biomass Accumulation," 2015; Rens et al. 2018; Zotarelli et al. 2015; Zotarelli et al. 2014)

Traditional plant nutrient studies are designed to reveal the limits of crop yield response to increasing availability of that nutrient, and using a simple quadratic model, maximum yields can be estimated. Figure 4 shows the overall total and marketable yield response of potato cultivars Atlantic and FL1867 to N-fertilizer rates conducted between 2011 and 2014 in multiple commercial potato fields. Maximum total and marketable tuber yield as the response of a quadratic model were reached with $\mathrm{N}$-fertilizer rates of $224-225 \mathrm{lb} / \mathrm{ac}$. The variability observed in the yield response to a given $\mathrm{N}$-fertilizer rate (indicated by the error bars) is evidence that non-fertilizer-related factors, including the seasonal variation of weather conditions (e.g., rainfall, temperature, irrigation, crop management), are also interfering in the yield response to fertilizer. Thus, the $\mathrm{N}$-fertilizer rate should not be seen as the only factor 
limiting production. $\mathrm{N}$-fertilizer application rates above 250 $\mathrm{lb} / \mathrm{acre}$ of $\mathrm{N}$ did not result in a significantly higher tuber yield with a wider $95 \%$ confidence band, which indicates a higher level of uncertainty regarding the expected yield response to fertilizer (Figure 4).

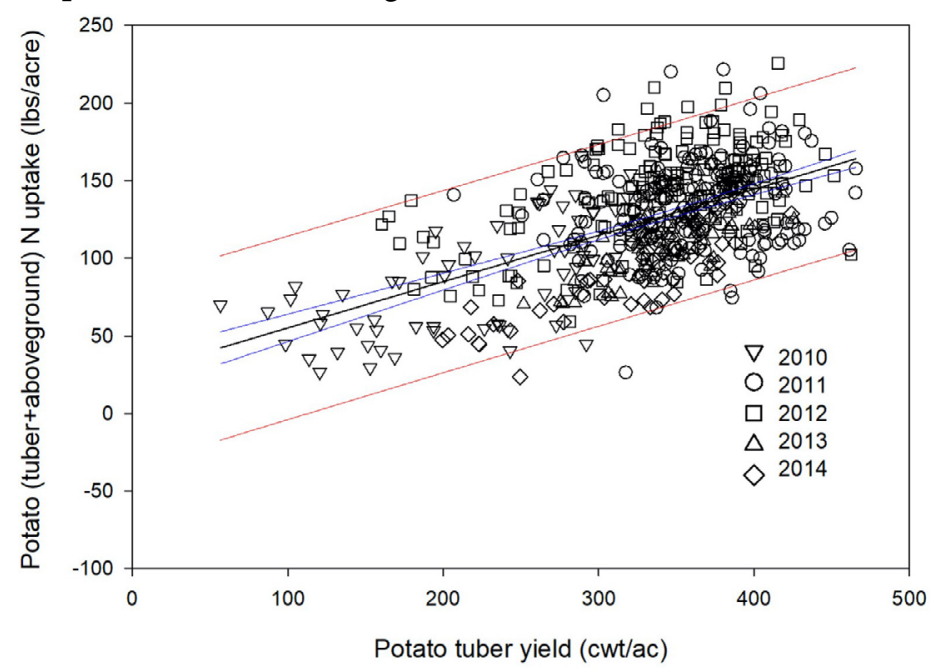

$$
\begin{array}{ll}
\nabla \quad \mathrm{N} \text { uptake } & \mathrm{N}_{\text {uptake }}=25.2876+\mathrm{Yld}^{*} 0.2980, p<0.001 \\
\hline \text { Linear regression } & n=576, \mathrm{r}^{2}=0.32 \\
\text { 95\% Confidence Band } & \\
95 \% \text { Prediction Band } &
\end{array}
$$

Figure 3. Relationship between total tuber yield (cwt/ac) and potato plant N uptake (shoots and tubers) of cultivars Atlantic and FL1867 (total number of observations $=576$ ) cultivated in six commercial fields of northeast Florida between 2010 and 2014.

Credits: Data source: (Rens et al., "Rate and Timing," 2015; Rens et al., "Commercial Evaluation," 2016; Rens et al., "Biomass Accumulation," 2015; Rens et al. 2018; Zotarelli et al. 2015; Zotarelli et al. 2014)
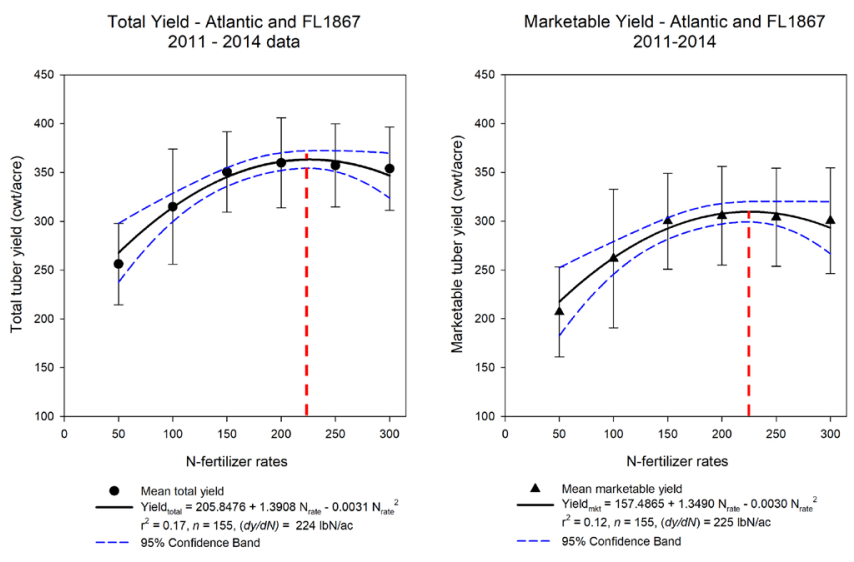

Figure 4. Total and marketable tuber yield response to $\mathrm{N}$-fertilizer rates for cultivars Atlantic and FL1867 cultivated in six commercial fields of northeast Florida between 2011 and 2014. The red dotted line indicates maximum total and marketable yield estimated by setting the first derivative of the quadratic equation generated by the regression analysis equal to zero. Error bars indicate standard deviation. The total number of observations $=155$.

Nitrogen fertilizer recommendation is defined by crop $\mathrm{N}$ requirement divided by NFUE (Scholberg et al. 2013). As tuber yield increases due to the favorable weather and cultivation conditions, potato plants will proportionally uptake more $\mathrm{N}$ from the soil to sustain the potential yield, as represented by the green line in Figure 5 . However, as the $\mathrm{N}$-fertilizer rate increases, the NFUE tends to decrease; consequently, an increasingly large fraction of the $\mathrm{N}$-fertilizer applied can be potentially lost from the production area. From the experimental data collected in these studies, the NFUE for the N-fertilizer rate of $200 \mathrm{lb} / \mathrm{acre}$ was about $45 \%$ or $0.45 \mathrm{lb}$ of plant biomass produced (tuber and aboveground) per $\mathrm{lb}$ of $\mathrm{N}$-fertilizer applied. With the increase of the $\mathrm{N}$-fertilizer rate to 250 and $300 \mathrm{lb} / \mathrm{acre}$ of $\mathrm{N}$, the NFUE reduced to $34 \%$ and $28 \%$, respectively (Rens et al., "Fertilizer Nitrogen Uptake Efficiencies," 2016; Zotarelli et al. 2014). Using the median total tuber yield and 5th and 95th percentile of the measured values from the field studies (Figure 2), it is possible to estimate the correspondent $\mathrm{N}$-fertilizer required using measured NFUE (Figure 5A). The median total tuber yield of $346 \mathrm{cwt} /$ acre required an $\mathrm{N}$-fertilizer rate of $222 \mathrm{lb} /$ acre of $\mathrm{N}$, while range yield values between 230 and $405 \mathrm{cwt} / \mathrm{acre}$ (90\% of the observations) required 152 and $254 \mathrm{lb} /$ acre of $\mathrm{N}$-fertilizer.
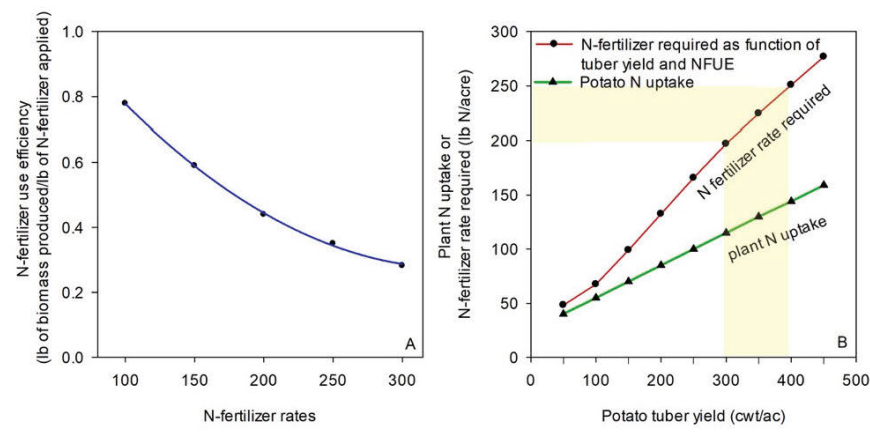

Figure 5. Potato $\mathrm{N}$-fertilizer use efficiency as a function of $\mathrm{N}$-fertilizer rate (A); and the relationship between total tuber yield (cwt/ac) and plant $\mathrm{N}$ uptake (lb/acre of N), N-fertilizer use efficiency (lb of biomass/ Ib of $\mathrm{N}$-fertilizer applied) and $\mathrm{N}$-fertilizer rate required (Ib/acre of $\mathrm{N}$ ) as a function of total tuber yield (cwt/ac) (B).

\section{Economic Analysis of N-Fertilizer Rate Application}

The assessment of the optimum N-fertilizer rate for potato production in Florida also requires economic profits analysis. Mwatuwa (2020) developed the enterprise budget for chip potato production in Florida and calculated gross revenue and net returns for increasing rates of $\mathrm{N}$-fertilizer based on the tuber yield outcomes from the above-cited studies. It was assumed that the total $\mathrm{N}$-fertilizer rate of $100 \mathrm{lb} /$ acre was divided into two applications, at preplant and plant emergence, while $\mathrm{N}$-fertilizer rates of $150 \mathrm{lb} /$ acre and above were split into three applications. Total and marketable yield data for Atlantic and FL1867 cultivars were averaged for each $\mathrm{N}$-fertilizer rate. 
An average market price of $\$ 14.50 / \mathrm{cwt}$ was used to calculate the gross revenue, and the average cost of adding $50 \mathrm{lb} /$ acre of $\mathrm{N}$-fertilizer was $\$ 24$. Production cost increased from $\$ 2,668$ to $\$ 2,745$ when $\mathrm{N}$-fertilizer rates increased from 150 to $300 \mathrm{lb} / \mathrm{acre}$ (in addition to fertilizer, other factors included are fuel, labor, and machine operating costs) (Table 1). Based on the marketable yields of the field studies and the fixed price of $\$ 14.5 / \mathrm{cwt}$, the average net return was highest at $\$ 1,772$ with a $\mathrm{N}$-fertilizer rate of $225 \mathrm{lb} /$ acre and an estimated yield of $309 \mathrm{cwt} / \mathrm{ac}$. Compared to the $225 \mathrm{lb} /$ acre application rate, the 250 and $300 \mathrm{lb} /$ acre rates resulted in reductions of average net return in $\$ 84$ (or $4.7 \%$ ) and $\$ 159 /$ acre (or $9.0 \%$ ), respectively (Table 1 ). Increased production costs combined with reduced marketable yield resulted in a reduction in the profit margin from $65 \%$ to $59 \%$ when increasing the $\mathrm{N}$-fertilizer rate from 225 to 300 $\mathrm{lb} / \mathrm{acre}$.

Variations in total and marketable yield outcomes observed for all $\mathrm{N}$-fertilizer rates suggested that other factors besides $\mathrm{N}$-fertilizer influenced yield. For example, weather, including rainfall events and temperature, soil characteristics, and management strategies influence potato growth and tuber yield outcomes. The standard deviation (Figure 2, error bars) indicates that for $\mathrm{N}$-fertilizer application of $200 \mathrm{lb} / \mathrm{ac}$, the marketable yield was expected to range from 256 to 356 cwt/acre (Figure 4 and Table 1). Thus, net returns ranging from $\$ 1,006$ to $\$ 2,472$ with profit margins of $37 \%$ to $92 \%$ were expected per acre. Another metric to consider is the average return per dollar spent on $\mathrm{N}$-fertilizer. The application rate of $200 \mathrm{lb} /$ acre of $\mathrm{N}$-fertilizer returned $\$ 12.30 / \mathrm{lb}$ of $\mathrm{N}$; as the $\mathrm{N}$-fertilizer rate increased to 225,250 , and 300 $\mathrm{lb} / \mathrm{ac}$, the return dropped to $\$ 12.03, \$ 11.46$, and $\$ 10.65$ per dollar spent in $\mathrm{N}$-fertilizer, respectively.

\section{N-Fertilizer Best Management Practices for Potatoes}

Best management practices are defined as a practice or combination of practices based on research, field-testing and expert review to the most effective and practical on-location means, including economic and technological considerations for improving water quality in agricultural discharges (FDACS 2015). Many factors considered for the design of a $\mathrm{N}$-fertilizer program for potatoes are based on the "Four Rs Principles," which include the right rate, right timing of application, right placement, and right source of fertilizer. More information on the general concepts of 4 Rs can be found in EDIS article SL411, "The Four Rs of Fertilizer Management” (https://edis.ifas.ufl.edu/ss624). The principles of plant nutrition presented in the BMP manual (FDACS 2015) are discussed below, emphasizing potatoes.

\section{Principle 1-Supplying the Right Amount of Nutrients Based on Total Yield Potential, Planting Date, and Cultivar}

The selection of a realistic $\mathrm{N}$-fertilizer rate for potatoes is an important decision that will directly impact yield, economic return, and $\mathrm{N}$ leaching. It is noteworthy that the $\mathrm{N}$-fertilizer rate is not the only factor that can limit tuber production. Other factors that may limit yield potential in potatoes include, but are not limited to, planting date, cultivars, soil type, weather conditions, phytosanitary management, and adequate irrigation. There is a direct correlation between tuber yield and plant $\mathrm{N}$ uptake (Figure 3), assuring that the required amount of $\mathrm{N}$ is available to plant uptake when the plant needs are critical for successful nutrient management.

Table 3 shows the $\mathrm{N}$-fertilizer requirement and expected plant $\mathrm{N}$ uptake (tuber and aboveground) according to the expected total yield goal. Yield potential for a given area can be assessed by historic total yield (not marketable yield) records considering planting date, previous $\mathrm{N}$-fertilizer application rates and timing, and cultivar. Ninety percent of the field trial observations for total yield were between 230 and $405 \mathrm{cwt} / \mathrm{ac}$, with the correspondent $\mathrm{N}$-fertilizer requirement of 150-250 lb/acre of $\mathrm{N}$.

Excessive application of $\mathrm{N}$-fertilizer will promote excessive vine growth and delay maturity, which can negatively impact tuber yield. Table stock potato cultivars are generally more sensitive to excessive $\mathrm{N}$-fertilizer rates, which can reduce quality by promoting malformation and a higher incidence of hollow heat in tubers. Also, N-fertilizer application above the yield goal will result in a larger amount of $\mathrm{N}$ not being utilized by the crop and susceptible to leaching. For northeast Florida, late planting dates (after the first week of March) have shown to reduce the potential yield by $13 \%-50 \%$ for chipping cultivars compared to late January and February planting dates (Worthington and Hutchinson 2005, 2006), and thus adjusting the $\mathrm{N}$-fertilizer rate according to yield goal for a given planting date is necessary. For specialty types of potatoes, such as creamer production, when tubers are immaturely harvested (e.g., vine kill around 50-55 days after planting), they will also require less $\mathrm{N}$-fertilizer.

Adjustments of the N-fertilizer rate can also be made accordingly to the soil organic matter and previous crop. The $\mathrm{N}$-fertilizer trials presented above had sorghum-sudangrass preceding potatoes. Therefore, the optimum $\mathrm{N}$-fertilizer 
rates have considered the potential tie-up of soil $\mathrm{N}$ by the microbial biomass, requiring no extra $\mathrm{N}$-fertilizer to compensate for soil $\mathrm{N}$ immobilization by the soil residues. Most of the potato-producing areas in the state have low levels of soil organic matter $(<1.4 \%)$; thus, the contribution of the soil organic matter may be relatively low $(<25 \mathrm{lb} /$ ac) compared to the crop demand for N. Besides, the soil organic mineralization rate is unknown and dependent on multiple factors, such as soil temperature and moisture, which can result in unsynchronized mineralization and plant uptake for a short crop season. A proportional reduction of the $\mathrm{N}$-fertilizer rate may be considered in areas with higher soil organic matter levels.

\section{Principle 2-Diminishing Returns}

Increasing $\mathrm{N}$-fertilizer rates showed a positive response to total and marketable tuber yield up to a rate of $225 \mathrm{lb} /$ acre of N. After that point, yield responses to increasing $\mathrm{N}$-fertilizer applications halt, and reductions in yield could occur. Because of the relatively low cost of $\mathrm{N}$-fertilizer, the maximum yield and economic return can be achieved with $\mathrm{N}$-fertilizer rates around $225 \mathrm{lb} / \mathrm{acre}$ of N. Further, several years of field experiments show that application of $\mathrm{N}$-fertilizer rates above $250 \mathrm{lb} / \mathrm{acre}$ of $\mathrm{N}$ did not increase total or marketable yield (Figure 4). Based on the economic analysis, raising the total $\mathrm{N}$-fertilizer applied from $225 \mathrm{lb} /$ acre to $250 \mathrm{lb} /$ acre of $\mathrm{N}$-fertilizer will reduce the gross revenue by $\$ 74 / \mathrm{ac}$, and raising it from $225 \mathrm{lb} / \mathrm{acre}$ to $300 \mathrm{lb} /$ acre of $\mathrm{N}$-fertilizer will diminish the gross revenue by $\$ 128$ / acre (Table 2).

\section{Principle 3-Fertilizer Placementand Timing}

Placement of $\mathrm{N}$-fertilizer near the root zone can increase NFUE in potatoes. About $92 \%$ of the potato roots are found in $0-10$ inches soil depth layer underneath the plant row and ridge (or hilled) area (Munoz-Arboleda et al. 2006). Less than $1 \%$ of the potato roots were found in the area corresponding to the alley (i.e., between ridges). Broadcasting, which is the even distribution of fertilizer over the surface of the cultivated area, is not encouraged for potato production because a significant part of the fertilizer applied will not reach the potato roots and will be susceptible to leaching. Banding fertilizer application, which is the placement of concentrated fertilizer along the crop row, is the most efficient method for potato crop. The first application at planting can be banded along the crop row and incorporated into the soil during the ridge formation. A side-dress application can be achieved by banding dry fertilizer along the crop row using fertilizer hopper tubes, followed by hilling. Liquid fertilizer can be knifed in along the crop row as well.

The establishment of proper $\mathrm{N}$-fertilizer application timing for potato production can effectively reduce $\mathrm{N}$-fertilizer leaching because of the improved synchronization with crop demand. The ideal fertilizer application window for potatoes is between planting and tuber initiation (approximately $50-55$ days after planting). In practice, two or three application timings can be considered. However, three application timings decrease the likelihood of losses by leaching compared to that of two applications. For two application timings, ideally, the first application should be conducted between planting and emergence with 30\%-40\% of the total $\mathrm{N}$-fertilizer rate, and the second application between emergence and the middle of growth stage II (vegetative growth) with the remaining $\mathrm{N}$-fertilizer amount. For three application timings, the $\mathrm{N}$-fertilizer can be applied at planting (or near planting), emergence, and the tuber initiation stage, with the proportion of $25 \%-30 \%, 40 \%-55 \%$, and $25 \%-30 \%$, respectively. These timing strategies will assure soil $\mathrm{N}$ availability to match plant $\mathrm{N}$ uptake demand (Figure 1). Preplant application of $\mathrm{N}$-fertilizer weeks before planting (e.g., at fumigation) is discouraged because of nitrate leaching risk due to rainfall events. Conversely, a large application rate of $\mathrm{N}$-fertilizer $(>75 \mathrm{lb} /$ acre of $\mathrm{N}$ ) late in the season may delay crop maturity and increase residual soil $\mathrm{N}$ after harvest, making it susceptible to leaching. Results from field trials have shown that $\mathrm{N}$-fertilizer rates above 50 $\mathrm{lb} / \mathrm{acre}$ of $\mathrm{N}$ applied at tuber initiation have not significantly resulted in higher tuber yield. This can be attributed to the fact that most cultivars used in Florida are early maturing, and they may benefit from having a higher proportion of $\mathrm{N}$ in the first two applications compared to the tuber initiation application.

In-season adjustment of $\mathrm{N}$-fertilizer can be made by evaluating the nitrate- $\mathrm{N}$ concentration in petiole leaves. Ideally, petiole samples should be taken before the last application of $\mathrm{N}$-fertilizer and hilling. Table 5 presents the adequate values for nitrate- $\mathrm{N}$ concentration in the petiole. Thus, an adjustment of the $\mathrm{N}$-fertilizer rate can be made for the last application timing before row closure. For potatoes cultivated under sprinkler irrigation with capabilities of fertigation, additional $\mathrm{N}$-fertilizer can be applied via fertigation; however, this type of application has much lower efficiency (i.e., equivalent to broadcasting fertilizer) than the in-row application of dry or liquid fertilizer and is much more susceptible to leaching after a rainfall event. 


\section{Principle 4-Fertilizer Sources}

$\mathrm{N}$-fertilizer sources can be found in ammoniacal and nitrate forms. In the soil, nitrate forms are preferred by plants for uptake, but they are also more susceptible to leaching than ammonium. Thus, in selecting $\mathrm{N}$-fertilizer sources, it is recommended that $25 \%-50 \%$ of the $\mathrm{N}$-fertilizer be supplied from nitrate sources (Liu et al. 2018). Also, the application of $\mathrm{N}$-fertilizers in liquid or dry form has not shown differences in yield response. Guidelines on the conversion from liquid to dry and vice-versa can be found in EDIS article HS1200, "How to Convert Liquid Fertilizer into Dry Fertilizer in Fertigation for Commercial Vegetable and Fruit Crop Production" (https://edis.ifas.ufl.edu/hs1200).

A successful $\mathrm{N}$-fertilization program can be achieved using water-soluble $\mathrm{N}$-fertilizer sources when the proper timing and rate of $\mathrm{N}$-fertilizer are chosen. The use of controlledrelease $\mathrm{N}$-fertilizers (CRF) or slow-release fertilizer (SLF) is not widely adopted by potato growers, mainly because of the higher cost compared to the water-soluble sources and the uncertainties in synchronization of nutrient release and plant uptake. More research is needed to match the synchronization of CRF N-fertilizer sources with fast potato plant growth. More information on the use of CRF can be found in EDIS article HS1255, "Controlled-Release and Slow-Release Fertilizers as Nutrient Management Tools" (https://edis.ifas.ufl.edu/hs1255).

\section{References}

da Silva, A. L. B. R., L. Zotarelli, M. D. Dukes, S. Agehara, S. Asseng, and E. van Santen. 2018. "Irrigation Method and Application Timing Effect on Potato Nitrogen Fertilizer Uptake Efficiency." Nutr. Cycl. Agroecosyst. 112:253-264. https://doi.org/10.1007/s10705-018-9942-6

FDACS. 2015. Water Quality/Quantity Best Management Practices for Florida Vegetable and Agronomic Crops. Tallahassee: Florida Department of Agriculture and Consumer Services. p. 103. Accessed April 7, 2021. https://www.fdacs. gov/content/download/77230/file/vegAgCropBMP-loRes. pdf

Gudmestad, N. C. 2008. "Potato Health from Sprouting to Harvest." In Potato Health Management, edited by D. A. Johnson, 67-78. St. Paul, MN: APS Press.

Hochmuth, G., and E. Hanlon. 2011. "A Summary of N, P, and K Research with Potatoes in Florida." EDIS 2011 (5/6). https://doi.org/10.32473/edis-cv233-2011
Liu, G. D., E. H. Simonne, K. T. Morgan, and G. J. Hochmuth. 2018. "Soil and Fertilizer Management for Vegetable Production in Florida.” EDIS 2015 (1). http://edis.ifas.ufl. $\mathrm{edu} / \mathrm{cv} 101$

Miller, J. S., and B. G. Hopkins. 2008. "Checklist for a Holistic Potato Health Management Plan.” In Potato Health Management, edited by D. A. Johnson, 7-10. St. Paul, MN: APS Press.

Munoz-Arboleda, F., R. S. Mylavarapu, C. M. Hutchinson, and K. M. Portier. 2006. "Root Distribution under SeepageIrrigated Potatoes in Northeast Florida." American Journal of Potato Research 83:463-472. https://doi.org/10.1007/ BF02883507

Mwatuwa, R. Z. 2020. “Economic Feasibility of Irrigation Methods and Nitrogen Fertilizer Strategies for Potato Production in Florida." Horticultural Sciences. University of Florida, Gainesville, FL, p. 117.

Rens, L., L. Zotarelli, A. Alva, D. Rowland, G. Liu, and K. Morgan. 2016. "Fertilizer Nitrogen Uptake Efficiencies for Potato as Influenced by Application Timing." Nutr. Cycl. Agroecosyst. 104:175-185. https://doi.org/10.1007/ s10705-016-9765-2

Rens, L. R., L. Zotarelli, D. J. Cantliffe, P. J. Stoffella, D. Gergela, and D. Burhans. 2015. "Rate and Timing of Nitrogen Fertilizer Application on Potato 'FL1867' Part II: Marketable Yield and Tuber Quality." Field Crops Research 183:267-275. https://doi.org/10.1016/j.fcr.2015.08.008

Rens, L. R., L. Zotarelli, D. J. Cantliffe, P. J. Stoffella, D. Gergela, and D. Burhans. 2016. "Commercial Evaluation of Seasonal Distribution of Nitrogen Fertilizer for Potato." Potato Research 59:1-20. https://doi.org/10.1007/ s11540-015-9304-6

Rens, L. R., L. Zotarelli, D. J. Cantliffe, P. J. Stoffella, D. Gergela, and D. Fourman. 2015. "Biomass Accumulation, Marketable Yield, and Quality of Atlantic Potato in Response to Nitrogen.” Agronomy Journal 107 (3): 931-942. https://doi.org/10.2134/agronj14.0408

Rens, L. R., L. Zotarelli, D. L. Rowland, and K. T. Morgan. 2018. "Optimizing Nitrogen Fertilizer Rates and Time of Application for Potatoes under Seepage Irrigation." Field Crops Research 215:49-58. https://doi.org/10.1016/j. fcr.2017.10.004 
Scholberg, J. M. S., L. Zotarelli, M. D. Dukes, M. OzoresHampton, and G. D. Liu. 2013. "Enhancing Fertilizer Efficiency in High Input Cropping Systems in Florida." Sustainable Agriculture Reviews 12:143-174. https://doi. org/10.1007/978-94-007-5961-9_5

Stanley, C. D., and G. Toor. 2010. "Florida Commercial Horticultural Production: Constraints Limiting Water and Nutrient Use Efficiency." HortTechnology 20 (1): 89-93. https://doi.org/10.21273/HORTTECH.20.1.89

Stark, J., and D. Westerman. 2008. "Managing Potato Fertility." In Potato Health Management, edited by D. A. Johnson, 55-66. St. Paul, MN: APS Press.

USDA-NASS. 2020. Potatoes: 2019 Summary (September 2020). https://www.nass.usda.gov/Publications/Todays_Reports/reports/pots0920.pdf. Accessed April 7, 2021.

Worthington, C. M., and C. M. Hutchinson. 2005. "Accumulated Growing Degree Days as a Model to Determine Key Developmental Stages and Evaluate Yield and Quality of Potato in Northeast Florida." Proc. Fla. State Hort. Soc. 118:98-101.

Worthington, C. M., and C. M. Hutchinson. 2006. "Yield and Quality of 'Atlantic' and 'Harley Blackwell' Potatoes as Affected by Multiple Planting Dates, Nitrogen Rates and Growing Degree Days." Proc. Fla. State Hort. Soc. 119:275-279.

Zotarelli, L., L. R. Rens, D. J. Cantliffe, P. J. Stoffella, D. Gergela, and D. Burhans. 2015. "Rate and Timing of Nitrogen Fertilizer Application on Potato 'FL1867'. Part I: Plant Nitrogen Uptake and Soil Nitrogen Availability." Field Crops Research 183:246-256. https://doi.org/10.1016/j. fcr.2015.08.007

Zotarelli, L., L. R. Rens, D. J. Cantliffe, P. J. Stoffella, D. Gergela, and D. Fourman. 2014. "Nitrogen Fertilizer Rate and Application Timing for Chipping Potato Cultivar Atlantic." Agronomy Journal 106 (6): 2215-2226. https://doi. org/10.2134/agronj14.0193 
Table 1. Average tuber marketable yield, breakeven for yield (cwt) and price in (\$), production costs, the net return, and profit margin for chip potato cultivated under seepage irrigation with the application of $\mathrm{N}$-fertilizer rates of 100, 150, 200, 250, and 300 $\mathrm{lb} / \mathrm{acre}$ in Florida. Adapted from Mwatuwa (2020).

\begin{tabular}{|c|c|c|c|c|c|c|}
\hline $\mathrm{N}$-fertilizer rate (Ib/ac) & 100 & 150 & 200 & $225 *$ & 250 & 300 \\
\hline Total yield (cwt std. dev.) & 31559 & 35141 & 36046 & 36145 & 35743 & 35443 \\
\hline Marketable yield (cwt std. dev.) & 26271 & 30048 & 30650 & 30950 & 30450 & 30154 \\
\hline 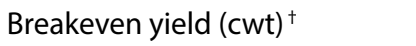 & 180 & 184 & 186 & 187 & 188 & 189 \\
\hline Breakeven price $(\$)^{\ddagger}$ & 9.97 & 8.89 & 8.81 & 8.76 & 8.95 & 9.13 \\
\hline Production cost (\$) & $2,611.01$ & $2,667.99$ & $2,693.64$ & $2,708.30$ & $2,719.35$ & $2,745.06$ \\
\hline Net return $(\$)^{\S}$ & $1,185.21$ & $1,683.90$ & $1,739.53$ & $1,772.20$ & $1,688.13$ & $1,613.24$ \\
\hline Net return range (\$) & 155 to 2,214 & 568 to 2,800 & 1,006 to 2,472 & 1,047 to 2,497 & 961 to 2,414 & 827 to 2,398 \\
\hline Profit margin & $45 \%$ & $63 \%$ & $65 \%$ & $65 \%$ & $62 \%$ & $59 \%$ \\
\hline Profit margin range & $6 \%-85 \%$ & $21 \%-105 \%$ & $37 \%-92 \%$ & $39 \%-92 \%$ & $35 \%-92 \%$ & $30 \%-87 \%$ \\
\hline \multicolumn{7}{|c|}{$\begin{array}{l}{ }^{\dagger} \text { Breakeven yield was calculated by dividing total production cost per acre by market price per cwt. } \\
\text { ₹ Breakeven price was calculated by dividing total production cost per acre by marketable yield. } \\
\text { \$T The average market price of } \$ 14.50 \text { per cwt was used to calculate gross revenue and net profit per acre. All costs were kept constant except } N \\
\text { fertilizer cost. } \\
\text { "Estimated total and marketable tuber yield using the quadratic equations presented in Figure } 4 .\end{array}$} \\
\hline
\end{tabular}

Table 2. The cumulative economic effect of $\mathrm{N}$ fertilizer rates $100,150,200,225,250$, and $300 \mathrm{lb} /$ acre on marketable yield of cultivars Atlantic and FL1867 in Florida.

\begin{tabular}{|c|c|c|c|c|c|}
\hline $\begin{array}{l}\text { 1. Total Application } \\
\text { of } N\end{array}$ & $\begin{array}{l}\text { 2. Cost of Fertilizer } \\
\text { NPK }^{+}\end{array}$ & 3. Marketable Yield & 4. Gross Revenue ${ }^{\ddagger}$ & 5. Total Return to $\mathrm{N}^{\S}$ & $\begin{array}{l}\text { 6. Average Return } \\
\text { per Dollar Spent } \\
\text { on } \mathrm{N}^{\varepsilon}\end{array}$ \\
\hline (lb/acre) & (\$/acre) & (cwt/acre) & (\$/acre) & (\$/acre) & $(\$ / \$ 1)$ \\
\hline 100 & $\$ 311.27$ & 262 & $\$ 3,796.23$ & $\$ 3,484.96$ & $\$ 12.20$ \\
\hline 150 & $\$ 335.77$ & 300 & $\$ 4,351.89$ & $\$ 4,016.12$ & $\$ 12.96$ \\
\hline 200 & $\$ 360.20$ & 306 & $\$ 4,431.93$ & $\$ 4,071.72$ & $\$ 12.30$ \\
\hline $225^{*}$ & $\$ 372.45$ & 309 & $\$ 4,480.50$ & $\$ 4,108.05$ & $\$ 12.03$ \\
\hline 250 & $\$ 384.69$ & 304 & $\$ 4,406.84$ & $\$ 4,022.15$ & $\$ 11.46$ \\
\hline 300 & $\$ 409.17$ & 301 & $\$ 4,358.27$ & $\$ 3,949.09$ & $\$ 10.65$ \\
\hline
\end{tabular}

'Total cost of $\mathrm{N}$ fertilizer represents a retail price of NPK fertilizer blend where PK rates were fixed at $100 \mathrm{lb} / \mathrm{acre}$ of $\mathrm{P}_{2} \mathrm{O}_{5^{\prime}} 300 \mathrm{lb} / \mathrm{acre}$ of $\mathrm{K}_{2} \mathrm{O}$, and additional 25 or $50 \mathrm{lb} / \mathrm{acre}$ of $\mathrm{N}$-fertilizer increments.

${ }^{\ddagger}$ Gross revenue was the product of marketable yield and market price of $\$ 14.50$ per cwt.

${ }^{5}$ Total return to $\mathrm{N}$-fertilizer applied was calculated by the difference between gross revenue and fertilizer cost (column $4-2$ ).

${ }^{\mathrm{E} A v e r a g e ~ r e t u r n ~ p e r ~ d o l l a r ~ s p e n t ~ o n ~} \mathrm{~N}$ was calculated by dividing gross revenue by fertilizer cost (column 4/column 2).

"Estimated total and marketable tuber yield using the quadratic equations presented in Figure 4.

Table 3. N-fertilizer rate required to achieve the yield goal for potatoes (cwt/ac) and respective potato plant $\mathrm{N}$ uptake in Florida.

\begin{tabular}{|c|c|c|}
\hline Total Tuber Yield Goal (cwt/ac) & Plant N Uptake (lb/ac) & N-Fertilizer Rate Required (lb/ac) \\
\hline 100 & 55 & 67 \\
\hline 150 & 70 & 100 \\
\hline 200 & 85 & 132 \\
\hline 250 & 100 & 166 \\
\hline 300 & 115 & 197 \\
\hline 350 & 130 & 224 \\
\hline 400 & 144 & 250 \\
\hline
\end{tabular}


Table 5. Adequate nitrate- $\mathrm{N}$ concentrations in fresh petiole sap of most recently matured leaves for potato crops at various periods in the season using the Hach or Quant-strip methods or Cardy meter. Adapted from Hochmuth et al. (2018). (EDIS article HS964:

https://edis.ifas.ufl.edu/ep081)

\begin{tabular}{|c|c|}
\hline Stage of Growth & Fresh Petiole Sap Concentration (ppm) $\mathbf{N O}_{\mathbf{3}}$-N \\
\hline Plants 8 inches tall & 1200 to 1400 \\
\hline First open flowers & 1000 to 1400 \\
\hline $50 \%$ flowers open & 1000 to 1200 \\
\hline $100 \%$ flowers open & 900 to 1200 \\
\hline Tops falling over & 600 to 900 \\
\hline
\end{tabular}

